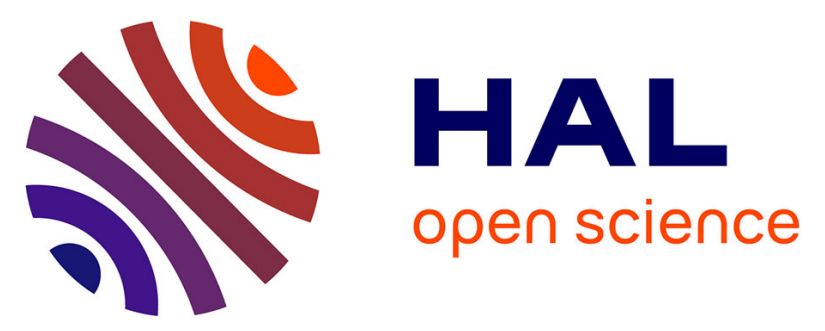

\title{
First Chemical Analysis and Characterization of the Male Species-Specific Cephalic Labial-Gland Secretions of South American Bumblebees
}

Nicolas Brasero, Baptiste Martinet, Klara Urbanova, Irena Valterova, Alexandra Torres, Wolfgang Hoffmann, Pierre Rasmont, Thomas Lecocq

\section{To cite this version:}

Nicolas Brasero, Baptiste Martinet, Klara Urbanova, Irena Valterova, Alexandra Torres, et al.. First Chemical Analysis and Characterization of the Male Species-Specific Cephalic Labial-Gland Secretions of South American Bumblebees. Chemistry and Biodiversity, 2015, 12 (10), pp.1535-1546. 10.1002/cbdv.201400375 . hal-01575790

\section{HAL Id: hal-01575790 \\ https://hal.univ-lorraine.fr/hal-01575790}

Submitted on 11 Dec 2020

HAL is a multi-disciplinary open access archive for the deposit and dissemination of scientific research documents, whether they are published or not. The documents may come from teaching and research institutions in France or abroad, or from public or private research centers.
L'archive ouverte pluridisciplinaire HAL, est destinée au dépôt et à la diffusion de documents scientifiques de niveau recherche, publiés ou non, émanant des établissements d'enseignement et de recherche français ou étrangers, des laboratoires publics ou privés. 
1 First chemical analysis and characterization of the male species-specific cephalic labial gland secretions of South American bumblebee

3 Nicolas Brasero ${ }^{a^{*}}$ ), Baptiste Martinet $^{\mathrm{a}}$ ), Klára Urbanováa ${ }^{\mathrm{b}^{*}}$ ), Irena Valterováb), Alexandra

4 Torres $^{c}$ ), Wolfgang Hoffmann ${ }^{c}$ ), Pierre Rasmont ${ }^{\mathrm{a}^{*}}$ ), Thomas Lecocq ${ }^{\mathrm{a}}$ )

$\left.5{ }^{a}\right)$ University of Mons, Research institute of Biosciences, Laboratory of Zoology, Place du 6 Parc 20, 7000 Mons, Belgium (phone: +3265373435; e-mail: nicolas.brasero@ umons.ac.be)

7 b) Academy of Sciences of the Czech Republic, Institute of Organic Chemistry and 8 Biochemistry, Flamingovo nám 2, CZ-166 10 Prague, Czech Republic (e-mail: 9 irena@uochb.cas.cz)

c) Grupo de Biocalorimetría, Facultad de Ciencias Bàsicas, Universidad de Pamplona, Km 1 vía Bucaramanga, Ciudadela Universitaria, Pamplona, Colombia (e-mail: datorres@unipamplona.edu.co)

*) Corresponding author

\section{Abstract}

The evolution of signals and reproductive traits involved in the pre-mating recognition has been in focus of abundant research in several model species group such as bumblebees (genus Bombus). However, the most studied bumblebee reproductive trait, the male cephalic labial gland secretions (CLGS), remains unknown among bumblebee species from South America. In this study we investigated the CLGS of five South American bumblebees of the subgenera Thoracobombus (Bombus excellens, B. atratus) and Cullumanobombus (B. rubicundus, B. hortulanus and B. melaleucus) comparing their secretions to those of European closely related species. Our results show an obvious interspecific differentiation in all subgenera. The 
interspecific differentiation in Thoracobombus involves different compounds with a large abundance (main compounds) while all Cullumanobombus share the same main components. This suggests that in Cullumanobombus subgenus differentiation in minor components could lead to species discrimination.

\section{Keywords}

Cephalic labial gland, Chemical reproductive traits, South America, bumblebees

\section{Introduction}

The pre-mating communication is of particular interest for evolutionary biologists because of its key role in sexual selection $[1,2]$. Therefore, the evolution of signals and reproductive traits involved in the pre-mating recognition has been widely studied [3] in several model species groups such as birds (e.g., [4-6]), moths (e.g. [7-9]) flies (e.g., [10-12]), or more recently the bumblebees (e.g., [13-15]).

The pre-mating recognition of bumblebees (genus Bombus) includes both chemical and behavioral features [16]. Most bumblebee males patrol along paths (i.e. patrolling behavior) where they scent-mark objects with their cephalic labial gland secretions (CLGS) $[17,18]$ that attract conspecific virgin females $[13,19]$. Other species exhibit less common behavior as perching behavior, in which males wait individually at prominent places and dart passing queens or other moving objects [20]. The CLGS is a complex mixture of (mainly aliphatic) compounds[18,21,22] produced de novo by the cephalic labial glands (acinar gland) [23] from saturated fatty-acids [24,25]. The resulting composition is species-specific [18]. The CLGS are thus an excellent tool for exploring interspecific and intraspecific variations of pre-mating recognition [13-15,26] as well as they are useful chemo-taxonomic characters [22,27-29]. 
Despite the usefulness of the CLGS as model in evolutionary biology and taxonomy, the male chemical secretions of a great number of species remain unknown [13]: the CLGS have been described for 50 species of a total of approximately 250 bumblebee species [30]. In several biogeographic regions such as South America, no studies have been published. Indeed, the CLGS chemical analyses require fresh samples [31] that are most of the time unavailable for uncommon taxa. In this paper, we investigated, the CLGS of males of five South American bumblebees: Bombus melaleucus Handlirsch, 1888 and B. hortulanus Friese, 1904 are near species belonging to the "Robustus group"(= Robustobombus sensu Richards, 1968 [32]) while B. rubicundus Smith, 1854 (Fig. 1 D) belongs to "Rubicundus group"(= Rubicundobombus sensu Richards, 1968 [32]), these species-groups being now included in Cullumanobombus subgenus [33]. B. atratus Franklin, 1913 (Fig. 1 B) and B. excellens Smith, 1879 (Fig. 1 A) both belong to the "Fervidus-species group"(= Fervidobombus sensu Richards, 1968 [32]) now all included in Thoracobombus subgenus [33]. We ultimately aim to compare their CLGS composition with those of related species from the same subgenus: $B$. (Thoracobombus) muscorum liepetterseni (L. 1758), B. (Thoracobombus) pascuorum melleofacies Vogt, 1911, B. (Cullumanobombus) cullumanus apollineus Skorikov, 1910 (Fig. 2 C) and B. (Cullumanobombus) semenoviellus Skorikov, 1910.

\section{Results and discussion}

\section{Composition of cephalic labial gland secretions}

Chemical analyses detected 146 compounds (33 from B. excellens, 35 from B. atratus, 53 from B. pascuorum, 19 from B. muscorum, 16 from B. rubicundus, 22 from B. hortulanus, 39 from B. melaleucus, 22 from B. cullumanus and 44 from B. semenoviellus ) (see Table 1). The results showed that all Thoracobombus species were differentiated in their CLGS composition (seven compounds shared by all species and 17 compounds shared between the two South 
American species), including changes in main compounds (octadec-11-enol (29\% - 46\%) in B. excellens and octadec-9-enol $(54 \%-91 \%)$ in B. atratus (Table 1). Inside the European taxa, hexadec-7-enol $(10 \%-31 \%)$ in B. pascuorum and octadec-9-enyl acetate in $B$. muscorum were the major compounds (Table 1). By main compounds of a taxon, we mean every compound that has the highest relative amount within the CLGS at least in one individual. Other differences between the South American Thoracobombus were mainly qualitative differences in minor compounds (Table 1). Similarly, the Cullumanobombus species displayed qualitative differences (only five compounds shared; six compounds shared between the three South American Cullumanobombus), but the main compound, geranylgeranyl acetate, is in common to all Cullumanobombus analyzed here: $81 \%-94 \%$ in B. rubicundus, $76 \%$ - $83 \%$ in B. hortulanus, $18 \%-59 \%$ in B. melaleucus, $51 \%-92 \%$ in B. cullumanus and 37\% - 60\% in B. semenoviellus. Qualitative variations differentiated species in minor components (Table 1).

\section{Stastistical analysis}

For both Thoracobombus and Cullumanobombus groups, the statistical analyses of the CLGS confirmed the interspecific differentiation (Fig. 2). This chemical differentiation is supported by high values of multiscale bootstrap resampling (> 80\%, Fig. 2). The interspecific differentiations between all consubgeneric species observed in our results are in agreement with the species-specificity of CLGS observed in other bumblebee groups (e.g., $[18,22,27,29])$. Similarly to our results on Thoracobombus species, the comparison of CLGS between closely related bumblebee taxa with a commonly recognized species status allow suggesting that the interspecific differentiation involves the change in main compounds (e.g., $[18,29,34])$. These main compound differentiations can be (i) a significant shift (production of new types of compounds, e.g., B. pascuorum versus B. muscorum) consecutive to switching off and on the respective metabolic pathway (e.g., [7]), (ii) large increase of a minor 
compound shared with closely related species (e.g., octadec-9-enyl acetate between $B$. muscorum versus $B$. atratus) [35], as well as (iii) difference in double bound position arisen by activity of different enzymes (e.g., $\Delta 11$-desaturase and $\Delta 9$-desaturase introducing a double bound in octadecenol in B. excellens and B. atratus, e.g., [8]) or by activation of a nonfunctional enzyme gene transcript present in a common ancestor, as observed in moths [9] and in other bumblebees [15]. In contrast, all Cullumanobombus species display the same main component (geranylgeranyl acetate) as observed in the North American $B$. (Cullumanobombus) rufocinctus Cresson, 1863 [20]. The geranylgeranyl acetate is also a main component of Bombus (Alpigenobombus) wurflenii [36], B. (Kallobombus) soroensis [37] and B. (Separatobombus) griseocollis [38] meaning that this component could not be considered as autapomorphic of Cullumanobombus. Assuming the key role of CLGS in premating recognition, this suggests that differentiation in minor compounds could lead to species discrimination. Moreover, for each CLGS group, the IndVal method revealed several significantly indicator compounds (see supplementary file 1).

\section{Conclusion}

The cephalic labial gland secretions of males are widely acknowledge as a useful and practical diagnostic trait for bumblebee species. Among the European bumblebee fauna, several taxonomically doubtful taxa groups have been solved thank to this reproductive trait. The present study is the first study to examine this trait among South American bumblebee species. This paves the way to a massive taxonomic assessment of South American bumblebees. 
123 The authors sincerely thank Peter Neumann (University of Bern, Switzerland) for his help in

124 providing contact for collecting the biological material. Financial support (IV and KU) was

125 provided by the Institute of Organic Chemistry and Biochemistry of the Academy of Sciences

126 of the Czech Republic (subvention for development of research organization RVO:

127 61388963). TL is post-doc in the context of the BELBEES project funded by the Belgian

128 Scientific Politic (BELSPO, BR/132/A1/BELBEES). The authors acknowledge the Fonds

129 pour la recherche dans l'industrie et l'agriculture (FRIA) for financial support (Project

130 2.4.564.06 F). Field trips of PR and TL in Sweden, Italy and in Turkey to collect material

131 have been funded by the Belgian FNRS. Thanks to B. Cederberg (Uppsala) and A.M. Aytekin

132 (Ankara) for their help. Special thanks to R. de Jonghe for the breeding of B. muscorum

133 liepetterseni males and to Nicolas R. Chimento (Laboratorio de Anatomía Comparada y

134 Evolución de los Vertebrados Museo Argentino de Ciencias Naturales "Bernardino

135 Rivadavia") for providing us pictures of Bombus atratus.

136

137

138

139

140

141

142

143

144

145

146 


\section{Experimental part}

149

150

151

152

153

154

155

156

157

158

159

160

161

162

163

164

165

166

167

168 169

\section{Biological material}

Fifty males from two subgenera were used for this study (Table 2): B. melaleucus (n=2), B. hortulanus $(\mathrm{n}=3)$, B. rubicundus $(\mathrm{n}=7)$, B.atratus $(\mathrm{n}=12)$, and B.excellens $(\mathrm{n}=2)$. As comparison group of Thoracobombus we used specimens already described in Lecocq et al. [28]: B. muscorum liepetterseni $(\mathrm{n}=5)$, B. pascuorum melleofacies $(\mathrm{n}=7)$. We used $B$. cullumanus apollineus $(\mathrm{n}=9)$ and B. semenoviellus $(\mathrm{n}=3)$ already described in [39] as comparison group of Cullumanobombus. We killed specimens by freezing at $-20^{\circ} \mathrm{C}$. The CLGS were extracted in $400 \mathrm{ml}$ of hexane [31]. Samples were stored at $-40^{\circ} \mathrm{C}$ prior to the analyses.

\section{Chemical analyses}

We identified the CLGS composition by gas chromatography-mass spectrometry (GC/MS) on a quadrupol Finigan GCQ, with a DB-5ms non-polar capillary column (5\% phenyl (methyl) polysiloxane stationary phase; $30-\mathrm{m}$ column length; $0.25-\mathrm{mm}$ inner diameter; $0.25-\mu \mathrm{m}$ film thickness). One $\mu \mathrm{l}$ was injected in splitless mode at the injector temperature set to $220^{\circ} \mathrm{C}$. The temperature of the column was initially held to $70^{\circ} \mathrm{C}$ for two minutes and then increased at a rate of $10^{\circ} \mathrm{C} / \mathrm{min}$ to $320^{\circ} \mathrm{C}$. The temperature was then held at $320^{\circ} \mathrm{C}$ for five minutes. The carrier gas was helium at a constant velocity of $50 \mathrm{~cm} / \mathrm{s}$. Compounds were identified using the retention times and mass spectra of each peak. Double bound positions were determined by DMDS (dimethyl disulfide) derivatization [40].

We analyzed all samples by a gas chromatograph-flame ionization detector Shimadzu GC2010 with a SLB-5ms non-polar capillary column (5\% phenyl (methyl) polysiloxane 
stationary phase; $30-\mathrm{m}$ column length; $0.25-\mathrm{mm}$ inner diameter; $0.25-\mu \mathrm{m}$ film thickness) with the same chromatographic conditions as in GC/MS.

Peak areas of compounds were detected in GCsolution Postrun (Shimadzu Corporation) with automatic peak detection and noise measurement. We calculated relative amounts (RA in \%) of compounds in each sample by dividing the peak areas of compounds by the total area of compounds in each sample. We did not use any correction factor to calculate the RA of individual compounds. We discarded all compounds for which RA were recorded as less than $0.1 \%$ for all specimens [31]. We elaborated the data matrix as the alignment of each compound between all samples performed with GCAligner $1.0[41,42]$ ( see supplementary file 1).

\section{Statistical analyses}

Statistical analyses were performed using R [43] to detected CLGS differentiations between specimen groups. Data consisting of the relative proportion of all compounds were transformed $(\log (\mathrm{x}-1))$ to reduce the large difference of abundance between highly and slightly concentrated compounds, and we then standardized $($ mean $=0$, standard deviation $=1)$ the data matrix to reduce the sample concentration effect [22]. Clustering method was used to detect the divergence between taxa. A Pearson Phi Correlation matrix based on CLGS data matrix (relative abundance of each compound) was computed. An unweighted pair group method with arithmetic mean (UPGMA) was used as clustering method (R-package ape,[44]). We assessed the uncertainty in hierarchical cluster analysis using $p$-values calculated via multiscale bootstrap resampling with 50.000 bootstrap replications (R-package pvclust,[44]). Only bootstrap values greater than $85 \%$ were considered significant. To determine compounds of each taxa (indicator compounds), we used the indicator value (IndVal) method $[45,46]$. The value given is the product of relative abundance and relative frequency of 
194 occurrence of a compound within a group. We evaluated the statistical significance of a

195

196

197

198

199

200

201

202

203

204

205

206

207

208

209

210

211

212

213

214

215

216

217

218 compound as an indicator at the 0.01 level with a randomization procedure. 
220

221

222

[1] H. E. H. Paterson, Evolution and the Recognition Concept of Species, The Johns Hopkins University Press, Baltimore, US, 1993.

[2] B. R. Grant, P. R. Grant, Evolution (N. Y). 1996, 50, 2471-2487.

[3] T. D. Wyatt, Pheromones and Animal Behaviour: Communication by Smell and Taste, Cambridge University Press, Cambridge, UK, 2003.

[4] M. I. Förschler, E. K. V Kalko, J. Biogeogr. 2007, 34, 1591-1600.

[5] J. Martens, in: Kroodsma, D.E., Miller, E.H., Eds., Ecology and Evolution of Acoustic Communication in Birds, Comstock Publishing, Ithaca, 1996, 221-240.

[6] G. L. Patricelli, J. A. C. Uy, G. Borgia, Proc. R. Soc. B Biol. Sci. 2003, 270, 23892395.

[7] N. Glaser, B. Frérot, E. Leppik, C. Monsempes, C. Capdevielle-Dulac, B. Le Ru, T. Lecocq, M. Harry, E. Jacquin-Joly, P.-A. Calatayud, J. Chem. Ecol. 2014, 40, 923-927.

[8] C. Löfstedt, Philos. Trans. R. Soc. B-Biological Sci. 1993, 340, 167-177.

[9] W. L. Roelofs, W. Liu, G. Hao, H. Jiao, A. P. Rooney, C. E. Linn Jr., Proc. Natl. Acad. Sci. U. S. A. 2002, 99, 13621-13626.

[10] M. R. E. Symonds, A. Moussalli, M. A. Elgar, Biol. J. Linn. Soc. 2009, 97, 594-603.

[11] C. R. B. Boake, Genetica 2002, 116, 205-214.

[12] J. E. Blyth, D. Lachaise, M. G. Ritchie, Ethology 2008, 114, 728-736.

[13] M. Ayasse, S. Jarau, Annu. Rev. Entomol. 2014, 59, 299-319.

[14] T. Lecocq, N. J. Vereecken, D. Michez, S. Dellicour, P. Lhomme, I. Valterová, J.-Y. Rasplus, P. Rasmont, PLoS One 2013, 8, e65642.

[15] T. Lecocq, S. Dellicour, D. Michez, P. Lhomme, M. Vanderplanck, I. Valterová, J.-Y. Rasplus, P. Rasmont, BMC Evol. Biol. 2013, 13, 263.

[16] B. Baer, Behav. Ecol. Sociobiol. 2003, 54, 521-533.

[17] G. Bergström, Entomol. Scand. Suppl. 1981, 15, 173-184.

[18] D. H. Calam, Nature 1969, 221, 856-857.

[19] A. Coppée, Bombus Terrestris (L. 1758) : A Complex Species or a Species Complex ? Intraspecific Pheromonal and Genetic Variations of Bombus Terrestris (L.), Impacts on the Speciation, Université de Mons Editor, 2010. 
[20] A. Bertsch, H. Schweer, A. Titze, J. Chem. Ecol. 2008, 34, 1268-1274.

[21] A. Coppée, M. Terzo, I. Valterová, P. Rasmont, Chem. Biodivers. 2008, 5, 2654-2661.

[22] T. Lecocq, P. Lhomme, D. Michez, S. Dellicour, I. Valterová, P. Rasmont, Syst. Entomol. 2011, 36, 453-469.

[23] B. Kullenberg, G. Bergström, B. Bringer, B. Carlberg, B. Cederberg, Zoon 1973, Suppl. 1, 23-30.

[24] P. Žáček, D. Prchalová-Hornákov, R. Tykva, J. Kindl, H. Vogel, A. Svatoš, I. Pichová, I. Valterová, ChemBioChem 2013, 14, 361-371.

[25] A. Luxová, I. Valterová, K. Stránský, O. Hovorka, A. Svatoš, Chemoecology 2003, 13, 81-87.

[26] P. Lhomme, M. Ayasse, I. Valterová, T. Lecocq, P. Rasmont, PLoS One 2012, 7, e43053.

[27] A. Bertsch, H. Schweer, A. Titze, H. Tanaka, Insectes Soc. 2005, 52, 45-54.

[28] T. Lecocq, N. Brasero, T. De Meulemeester, D. Michez, S. Dellicour, P. Lhomme, R. de Jonghe, I. Valterová, K. Urbanová, P. Rasmont, Anim. Conserv. 2014, DOI: $10.1111 / \mathrm{acv} .12164$

[29] P. Rasmont, M. Terzo, A. M. Aytekin, H. Hines, K. Urbanova, L. Cahlikova, I. Valterova, Apidologie 2005, 36, 571-584.

[30] P. H. Williams, Bull. Nat. Hist. Museum 1998, 67, 79-152.

[31] T. De Meulemeester, P. Gerbaux, M. Boulvin, A. Coppée, P. Rasmont, Insectes Soc. 2011, 58, 227-236.

[32] O. W. Richards, Bull. Br. Museum Natural Hist. Entomol. 1968, 22, 211-276.

[33] P. H. Williams, S. A. Cameron, H. M. Hines, B. Cederberg, P. Rasmont, Apidologie 2008, 39, 46-74.

[34] A. Bertsch, H. Schweer, Biochem. Syst. Ecol. 2012, 40, 103-111.

[35] M. Terzo, K. Urbanová, I. Valterová, P. Rasmont, Apidologie 2005, 36, 85-96.

[36] B. G. Svensson, M. Appelgren, G. Bergstrom, Nov. acta Regiae Soc. Sci.1984, 3, 145147.

[37] B. Kullenberg, G. Bergström, S. Ställberg-Stenhagen, Acta Chem. Scand. 1970, 24,1481 
[38] A. Bertsch, H. Schweer, A. Titze, Zeitschrift fur Naturforsch. - Sect. C J. Biosci. 2004, 59, 701-707.

[39] O. Hovorka, I. Valterová, P. Rasmont, M. Terzo, Chem. Biodivers. 2006, 3, 1015-22.

[40] J. Cvacka, E. Kofronová, S. Vasícková, K. Stránský, P. Jiros, O. Hovorka, J. Kindl, I. Valterová, Lipids 2008, 43, 441-50.

[41] S. Dellicour, T. Lecocq, GCALIGNER 1.0 and GCKOVATS 1.0 - Manual of a Software Suite to Compute a Multiple Sample Comparison Data Matrix from Eco-Chemical Datasets Obtained by Gas Chromatography, University of Mons, Mons (Belgium), 2013.

[42] S. Dellicour, T. Lecocq, J. Sep. Sci. 2013, 36, 3206-9.

[43] R Development Core Team (2013). R: a language and environment for statistical computing. Vienna: R Foundation for Statistical Computing. ISBN 3-900051-07-0. http://www.R-project.org (accessed 2 January 2014).

[44] R. Suzuki, H. Shimodaira, Pvclust: Hierarchical Clustering with P-Values via Multiscale Bootstrap Resampling 2011, R package version 1.2-2.

[45] J. Claudet, D. Pelletier, J.-Y. Jouvenel, F. Bachet, R. Galzin, Biol. Conserv. 2006, 130, 349-369.

[46] M. Dufrêne, P. Legendre, Ecol. Monogr. 1997, 67, 345-366.

(1) 
Table 1. List of the identified compounds in the Thoracobombus and Cullumanobombus subgenera. Molecular Weight (MW), median (M [\%]) of the 146 identified compounds. For each species, main compounds are shown on black background, characteristic compounds calculated with the full table with first and fourth quartile (Q1 and Q4 [\%]) are in the supplementary file 1

310

\begin{tabular}{|c|c|c|c|c|c|c|c|c|c|c|}
\hline Compounds & MW & B. atratus & B. excellens & B.pascuorum & B. mиscorum & B. hortulanus & B. melaleucus & B. rubicundus & B. cullumanus & $\begin{array}{c}B . \\
\text { semenoviellus }\end{array}$ \\
\hline & & M & M & M & M & M & M & M & M & M \\
\hline Octanoic acid & 144 & - & - & - & - & 0.40 & 0.10 & - & - & - \\
\hline Decanoic acid & 172 & - & - & - & - & - & 0.30 & - & - & - \\
\hline U1 & $?$ & - & - & - & - & 0.16 & - & - & - & - \\
\hline Dodecanoic acid & 200 & - & - & - & - & - & - & - & - & 0.07 \\
\hline Tetradecenol & 212 & - & - & 0.05 & - & - & - & - & - & - \\
\hline
\end{tabular}




\begin{tabular}{|c|c|c|c|c|c|c|c|c|c|c|}
\hline Dodecyl acetate & 228 & - & - & - & - & 0.09 & - & - & - & - \\
\hline Hexadec-7-enol & 240 & - & - & 24.12 & - & - & - & - & - & - \\
\hline Heptadecane & 240 & - & - & - & - & - & 0.07 & - & - & - \\
\hline Hexadecanol & 242 & - & - & 0.31 & - & - & - & - & - & - \\
\hline Tetradecyl acetate & 256 & - & - & - & - & 1.52 & 0.13 & - & - & - \\
\hline Farnesyl acetate & 264 & - & - & - & - & 1.49 & 0.10 & - & 0.11 & 0.31 \\
\hline Hexadecanol & 242 & - & - & - & - & - & - & - & - & 3.32 \\
\hline Hexadec-9-enoic acid & 254 & - & - & - & - & - & - & - & - & 6.49 \\
\hline Alpha-Springene & $?$ & - & - & - & - & - & - & - & - & 0.19 \\
\hline Hexadecanoic acid & 256 & - & - & 0.32 & - & - & 3.03 & - & - & 2.40 \\
\hline U3 & $?$ & - & - & - & - & - & - & 0.48 & - & - \\
\hline $\mathrm{U} 4$ & $?$ & - & - & - & - & 0.15 & - & - & - & - \\
\hline Octadecanal & 268 & - & - & - & - & - & - & 0.12 & - & - \\
\hline
\end{tabular}




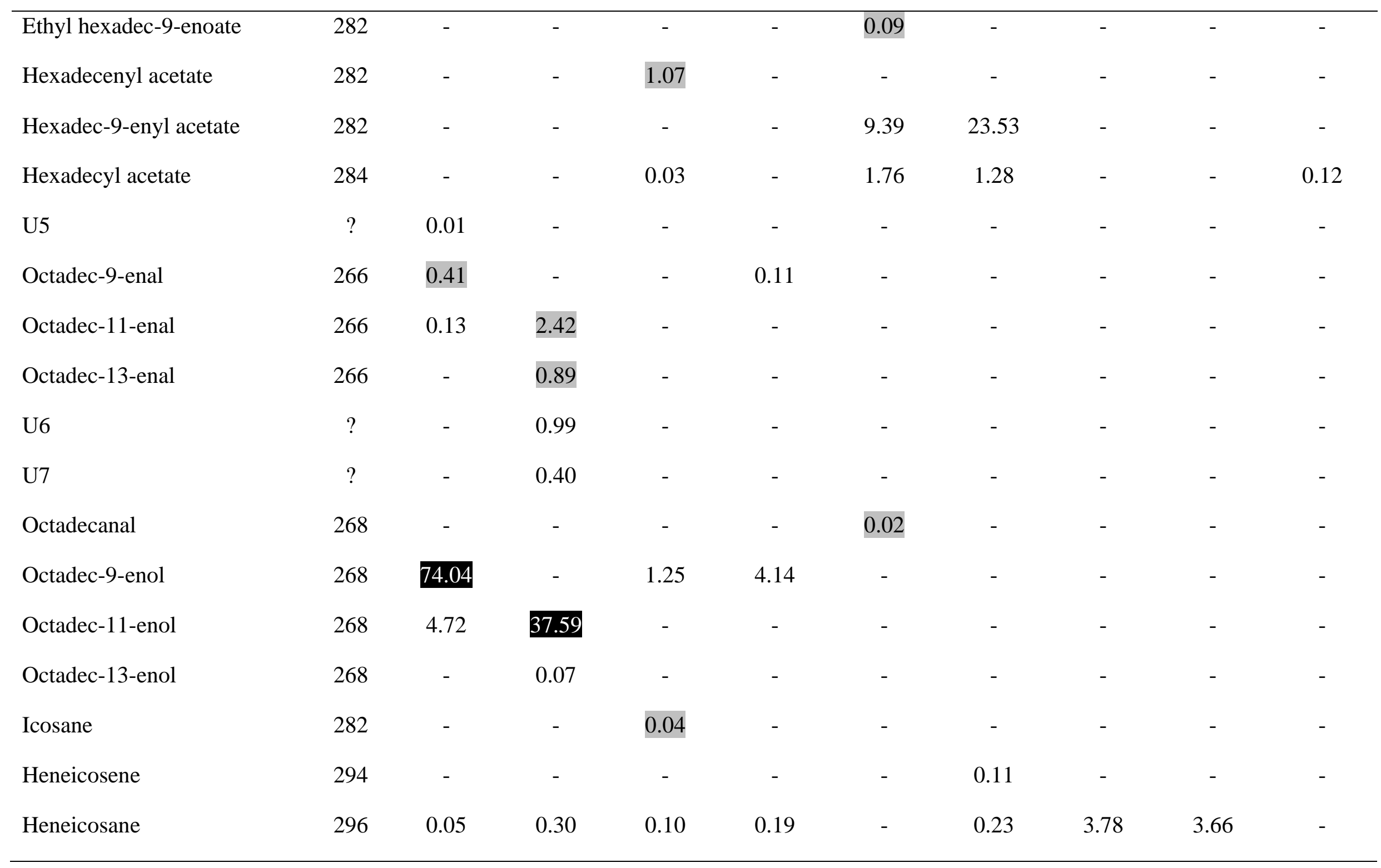




\begin{tabular}{|c|c|c|c|c|c|c|c|c|c|c|}
\hline U8 & $?$ & - & - & 0.08 & - & - & - & - & - & - \\
\hline Ethyl octadecenoate & 310 & - & - & - & - & - & - & 0.50 & 0.11 & - \\
\hline Geranyl geranial & 288 & - & - & - & - & - & 0.19 & 0.29 & - & - \\
\hline Geranyl decanoate & 308 & - & - & - & - & - & - & - & - & 0.31 \\
\hline Octadecenoic acid & 282 & - & - & 2.84 & - & - & - & - & - & - \\
\hline Octadec-9-enoic acid & 282 & - & - & - & - & - & - & - & - & 1.73 \\
\hline Octadec-11-enoic acid & 282 & - & - & - & - & - & 21.41 & - & - & - \\
\hline U11 & $?$ & - & - & - & - & - & 0.07 & - & - & - \\
\hline Unidentified terpene 1 & $?$ & - & - & - & - & - & - & - & - & 0.09 \\
\hline U12 & $?$ & - & 0.07 & - & - & - & - & - & - & - \\
\hline Ethyl octadecatrienoate & 306 & - & 3.92 & - & - & - & 0.23 & - & 0.07 & - \\
\hline U13 & $?$ & - & 0.93 & - & - & - & - & - & - & - \\
\hline Ethyl octadec-9-enoate & 310 & 0.00 & - & - & - & - & - & - & - & - \\
\hline
\end{tabular}




\begin{tabular}{|c|c|c|c|c|c|c|c|c|c|c|}
\hline Octadec-9-enyl acetate & 310 & 1.16 & - & - & 88.19 & - & 2.12 & - & - & - \\
\hline Octadecadienyl acetate & 308 & 0.02 & - & - & - & - & - & - & - & - \\
\hline Octadecenyl acetate & 310 & - & - & 0.47 & - & - & - & - & - & - \\
\hline Icosenal & 294 & - & 0.12 & - & - & - & - & - & - & - \\
\hline Octadecadienyl acetate2 & 308 & - & 0.17 & - & - & - & - & - & - & - \\
\hline Dodecyl octanoate & 312 & - & - & - & - & - & - & - & - & 0.14 \\
\hline Geranylgeranyl acetate & 322 & - & - & - & - & 82.93 & 38.42 & 91.77 & 87.94 & 48.08 \\
\hline Tricos-5-ene & 322 & 0.07 & - & - & - & - & - & - & - & - \\
\hline Tricosane & 324 & 2.91 & 8.72 & 3.46 & 2.63 & - & 1.06 & - & - & - \\
\hline Unidentified terpene 2 & $?$ & - & - & - & - & - & - & - & - & 0.00 \\
\hline Geranyl dodecanoate & 336 & - & - & - & - & - & - & - & - & 0.99 \\
\hline Tetracos-9-ene & 336 & 0.00 & 2.91 & 0.02 & - & - & - & - & - & - \\
\hline Tetracosene & 336 & - & - & 0.07 & - & - & - & - & - & - \\
\hline
\end{tabular}




\begin{tabular}{|c|c|c|c|c|c|c|c|c|c|c|}
\hline Tetracosane & 338 & 0.09 & - & 0.11 & 0.21 & - & 0.06 & - & 0.07 & 0.11 \\
\hline Icosenyl acetate2 & 338 & 0.02 & - & - & - & - & - & - & - & - \\
\hline Icosyl acetate & 338 & - & 0.88 & - & - & - & - & - & - & - \\
\hline Dodecyl decanoate & 340 & - & - & - & - & - & - & - & - & 1.22 \\
\hline Pentacos-9-ene & 350 & 0.75 & 0.43 & 3.49 & 0.47 & - & 0.19 & 0.09 & 0.09 & 0.17 \\
\hline Pentacos-7-ene & 350 & 0.78 & 0.75 & 0.00 & 0.36 & 0.07 & 0.15 & - & 0.94 & 0.50 \\
\hline Pentacosane & 352 & 0.13 & 2.61 & 2.09 & 1.78 & 0.65 & 1.48 & 1.71 & 2.45 & 2.10 \\
\hline Dodecyl dodecanoate & 368 & - & - & - & - & - & - & - & - & 4.85 \\
\hline Hexacosene2 & 364 & 1.71 & - & 0.09 & - & - & - & - & - & - \\
\hline Hexacosane & 366 & - & - & 0.07 & - & - & - & - & - & 0.07 \\
\hline Docosenyl acetate & 366 & - & - & - & 0.19 & - & - & - & - & - \\
\hline Heptacosadiene 1 & 376 & - & - & - & - & - & - & - & 0.14 & - \\
\hline Heptacosadiene2 & 376 & - & - & - & - & - & - & - & 0.09 & - \\
\hline
\end{tabular}




\begin{tabular}{|c|c|c|c|c|c|c|c|c|c|c|}
\hline Heptacos-9-ene & 378 & 0.12 & 0.24 & 1.61 & 0.32 & 0.12 & - & - & 0.12 & 0.19 \\
\hline Heptacosane & 380 & 0.13 & 0.69 & 0.80 & 0.36 & 0.47 & 1.05 & 0.68 & 1.15 & 1.02 \\
\hline Geranyl hexadec-7-enoate & 390 & - & - & - & - & - & - & - & - & 0.24 \\
\hline Octacosene & 392 & - & - & 0.05 & - & - & - & - & - & - \\
\hline Unidentified terpene 3 & $?$ & - & - & - & - & - & - & - & - & 0.34 \\
\hline U14 & $?$ & - & - & - & - & - & - & - & - & 0.05 \\
\hline Dodecyl tetradecanoate & 396 & - & - & - & - & - & - & - & - & 1.19 \\
\hline Nonacosadiene2 & 404 & - & - & - & - & - & - & - & 0.11 & - \\
\hline Nonacos-9-ene & 406 & 0.06 & 0.15 & 0.94 & 0.12 & 0.07 & - & 0.10 & 0.50 & 0.21 \\
\hline Nonacos-7-ene & 406 & 0.03 & 0.18 & - & - & 0.24 & 0.22 & 0.19 & - & 0.44 \\
\hline Nonacosane & 408 & 0.06 & - & 0.57 & 0.08 & 0.24 & 0.40 & 0.26 & 0.23 & 0.21 \\
\hline Unidentified terpene 4 & $?$ & - & - & - & - & - & - & - & - & 0.09 \\
\hline Triacontene1 & 422 & - & - & 0.02 & - & - & - & - & - & - \\
\hline
\end{tabular}




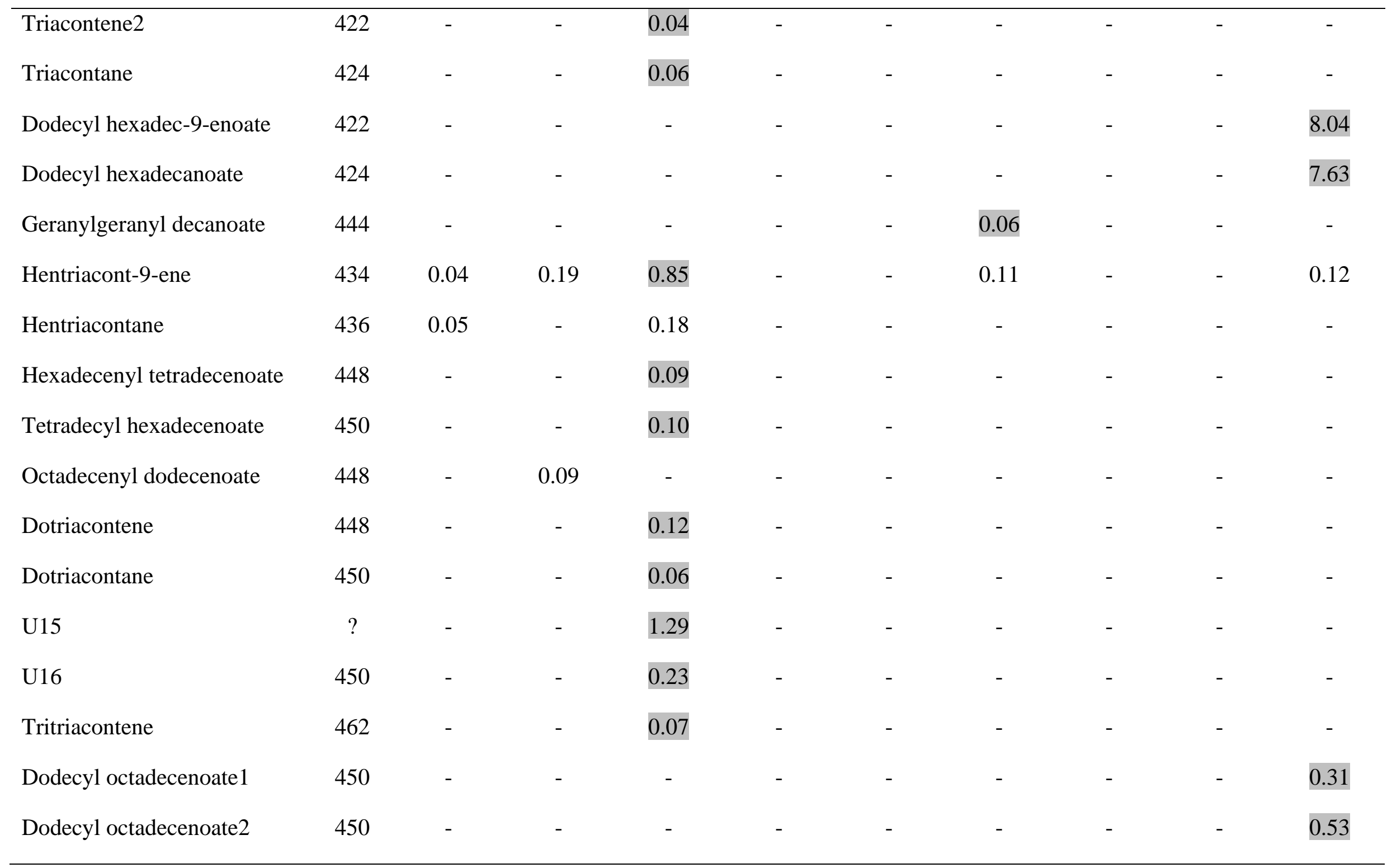




\begin{tabular}{|c|c|c|c|c|c|c|c|c|c|c|}
\hline Hexadecyl tetradecanoate & 452 & - & - & - & - & - & - & - & - & 0.21 \\
\hline Octadecenyl & $476 /$ & & & & & & & & & \\
\hline tetradecenoate/tetradecanoate & 478 & - & 0.12 & - & - & - & - & - & - & - \\
\hline Hexadecenyl hexadecenoate & 476 & - & - & 16.19 & - & - & 0.06 & - & - & - \\
\hline Hexadecyl hexadec-9-enoate & 478 & - & - & - & - & - & - & - & - & 2.90 \\
\hline Hexadecyl hexadecanoate & 480 & - & - & - & - & - & - & - & - & 0.51 \\
\hline $\begin{array}{l}\text { Hexadecenyl } \\
\text { octadecatrienoate }\end{array}$ & 500 & - & - & 0.33 & - & - & 0.11 & - & - & - \\
\hline $\begin{array}{l}\text { Octadecadienyl } \\
\text { hexadecenoate }\end{array}$ & 502 & - & 1.66 & - & - & - & - & - & - & - \\
\hline Hexadecenyl octadecenoate & 504 & - & - & 1.10 & - & - & - & - & - & - \\
\hline Octadecenyl hexadecenoate & 504 & - & 3.92 & - & - & - & - & - & - & - \\
\hline Hexadecyl octadecenoate & 506 & - & - & 0.04 & - & - & 0.06 & - & - & 0.09 \\
\hline Octadecenyl hexadecanoate1 & 506 & 0.23 & - & - & 0.05 & - & - & - & - & - \\
\hline Octadecenyl hexadecanoate2 & 506 & 0.13 & - & - & - & - & - & - & - & - \\
\hline U17 & ? & 0.07 & - & - & - & - & - & - & - & - \\
\hline
\end{tabular}




\begin{tabular}{|c|c|c|c|c|c|c|c|c|c|c|}
\hline $\begin{array}{l}\text { Geranylgeranyl } \\
\text { hexadecanoate }\end{array}$ & 528 & - & - & - & - & - & 0.41 & - & - & - \\
\hline U18 & $?$ & - & - & - & - & - & 0.17 & - & - & - \\
\hline $\begin{array}{l}\text { Octadecadienyl } \\
\text { octadecenoate }\end{array}$ & 530 & - & - & 2.02 & - & - & - & - & - & - \\
\hline Octadecenyl octadecenoate & 532 & - & - & 3.37 & 0.57 & - & - & - & - & - \\
\hline $\begin{array}{l}\text { Octadecenyl } \\
\text { octadecatrienoate }\end{array}$ & 528 & 1.04 & - & - & - & - & - & - & - & - \\
\hline
\end{tabular}


Table 2. Data on Collection of Biological Material. Collecting sites and number $(\mathrm{N})$ of samples collected for Bombus atratus, B. excellens, B. pascuorum melleofacies, B. muscorum

313 liepetterseni, B. hortulanus, B. melaleucus, B. rubicundus, B. cullumanus apollineus and B. 314 semenoviellus. Coordinate are given with the reference to the WGS84.

\begin{tabular}{|c|c|c|c|}
\hline Taxa & Collecting sites & Coordinates & $\overline{\mathbf{N}}$ \\
\hline \multicolumn{4}{|l|}{ Thoracobombus subgenus } \\
\hline \multirow[t]{2}{*}{ B. atratus } & Colombia, Pamplona & $7^{\circ} 22^{\prime} \mathrm{N} 72^{\circ} 39^{\prime} \mathrm{W}$ & 4 \\
\hline & Colombia, Tenjo & $4^{\circ} 52^{\prime} \mathrm{N} 74^{\circ} 09^{\prime} \mathrm{W}$ & 8 \\
\hline \multirow[t]{2}{*}{ B. excellens } & Colombia, Cundinamarca & $4^{\circ} 34^{\prime} \mathrm{N} 74^{\circ} 20 \mathrm{~W}$ & 1 \\
\hline & Colombia, Pamplona & $7^{\circ} 22^{\prime} \mathrm{N} 72^{\circ} 39^{\prime} \mathrm{W}$ & 1 \\
\hline \multirow[t]{2}{*}{ B. pascuorum melleofacies } & Italy, Torre d'Isola & $45^{\circ} 13^{\prime} \mathrm{N} 9^{\circ} 02^{\prime} \mathrm{E}$ & 4 \\
\hline & Italy, Cellara & $39^{\circ} 13^{\prime} \mathrm{N} 16^{\circ} 20^{\prime} \mathrm{E}$ & 3 \\
\hline B. muscorum liepetterseni & Norway, Flatanger & $64^{\circ} 28^{\prime} \mathrm{N} 10^{\circ} 43^{\prime} \mathrm{E}$ & 5 \\
\hline \multicolumn{4}{|l|}{ Cullumanobombus subgenus } \\
\hline \multirow[t]{2}{*}{ B. hortulanus } & Colombia, Pamplona & $7^{\circ} 21^{\prime} \mathrm{N} 72^{\circ} 41^{\prime} \mathrm{W}$ & 2 \\
\hline & Colombia, Cundinamarca & $4^{\circ} 34^{\prime} \mathrm{N} 74^{\circ} 01^{\prime} \mathrm{W}$ & 1 \\
\hline B. melaleucus & Colombia, Pamplona & $7^{\circ} 32^{\prime} \mathrm{N} 72^{\circ} 37^{\prime} \mathrm{W}$ & 2 \\
\hline B. rubicundus & Colombia, Pamplona & $7^{\circ} 20^{\prime} \mathrm{N} 72^{\circ} 37^{\prime} \mathrm{W}$ & 7 \\
\hline \multirow[t]{3}{*}{ B. cullumanus apollineus } & Turkey, Kars, Çıldır gölü & $40^{\circ} 55^{\prime} \mathrm{N} 43^{\circ} 16^{\prime} \mathrm{E}$ & 2 \\
\hline & Turkey, Kars, Göldalı & $40^{\circ} 58^{\prime} \mathrm{N} 43^{\circ} 18^{\prime} \mathrm{E}$ & 5 \\
\hline & Turkey, Kars, Çanaksu & $41^{\circ} 00^{\prime} \mathrm{N} 43^{\circ} 18^{\prime} \mathrm{E}$ & 2 \\
\hline B. semenoviellus & Czech Republic, Krkonoše & $50^{\circ} 41^{\prime} \mathrm{N} 15^{\circ} 51^{\prime} \mathrm{E}$ & 3 \\
\hline
\end{tabular}



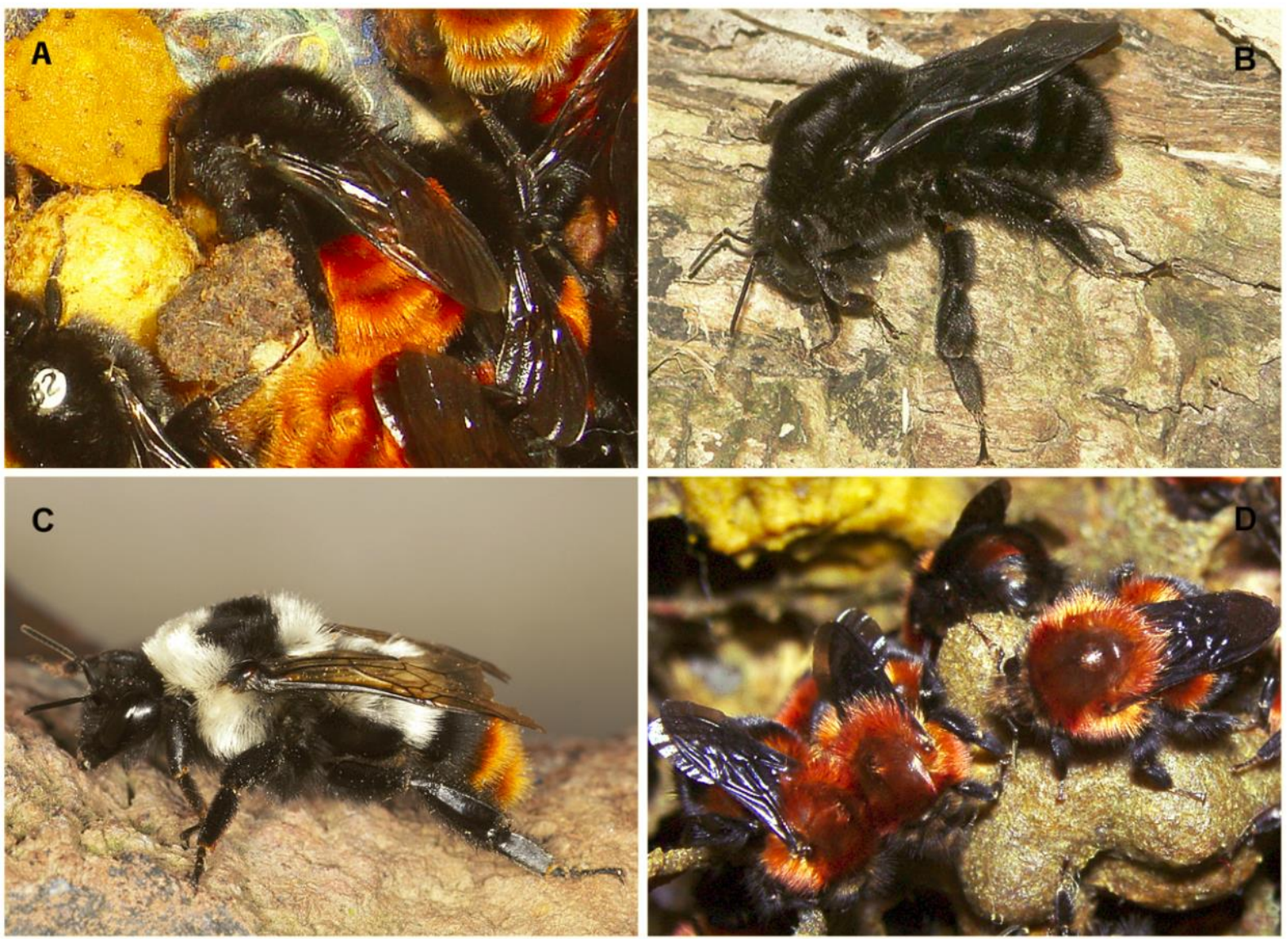

319 Figure 1. A: Bombus excellens from Colombia (photo: W. Hoffmann). B: Bombus atratus

320 from Argentina ( photo: N. Chimento). C: Bombus cullumanus apollineus from Turkey

321 (photo: P. Rasmont). D: Bombus rubicundus from Colombia (photo: W. Hoffmann) 


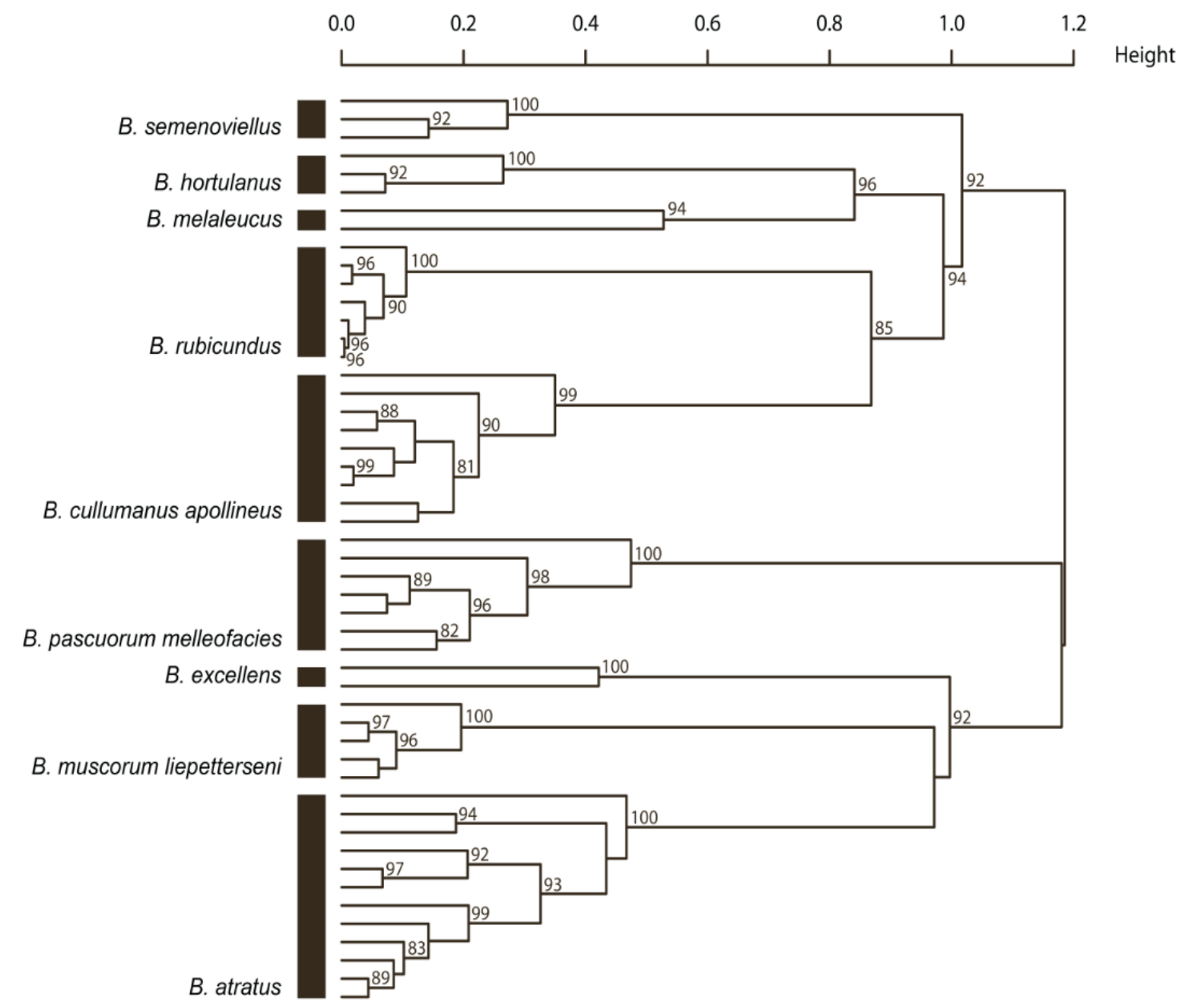

324 Figure 2. Unweighted pair group method with arithmetic mean cluster based on a correlation 325 matrix calculated from matrix of cephalic labial gland secretions of Bombus atratus, $B$. 326 excellens, B. pascuorum melleofacies, B. muscorum liepetterseni, B. hortulanus, B. 327 melaleucus, B. rubicundus, B. cullumanus apollineus and B. semenoviellus. Values above 328 branch represent multiscale bootstrap resampling (only values $>80 \%$ are given) 